\title{
The Effect of Campylobacter concisus on Expression of IL-18, TNF- $\alpha$ and p53 in Barrett's Cell Lines
}

\author{
Behrooz Mozaffari Namin, ${ }^{1,2}$ Mohammad Mehdi Soltan Dallal, ${ }^{3,4, *}$ and Nasser Ebrahimi \\ Daryani $^{5}$
}

${ }^{1}$ Department of Microbiology of Pathobiology, School of Public Health, Tehran University of Medical Sciences, International Campus (TUMS-IC), Tehran, IR Iran

${ }_{2}^{2}$ Microbiology and Gut Biology Group, University of Dundee, Ninewells Hospital Medical School, Dundee, UK

${ }^{3}$ Food Microbiology Research Center, Department of Pathobiology, School of Public Health, Tehran University of Medical Sciences, Tehran, IR Iran

${ }^{4}$ Food Microbiology Research Center, Tehran University of Medical Sciences, Tehran, IR Iran

${ }^{5}$ Department of Gastroenterology and Hepatology, School of Medicine, Tehran University of Medical Sciences, Tehran, IR Iran

${ }^{*}$ Corresponding author: Mohammad Mehdi Soltan Dallal, Food Microbiology Research Center, Department of Pathobiology, School of Public Health, Tehran University of Medical Sciences, Tehran, IR Iran. Tel: +98-2188992971, Fax: +98-2188954913, E-mail: msoltandallal@gmail.com

Received 2015 January 3; Revised 2015 February 24; Accepted 2015 March 7.

\begin{abstract}
Background: Barrett's oesophagus is a pre-malignant condition at gastroesophageal junction in which normal squamous epithelium is replaced by columnar shape epithelium, which predisposes oesophageal adenocarcinoma. It is known that Barrett's oesophagus evolves as a consequence of chronic gastro-oesophageal reflux disease. Although progression of Barrett's oesophagus to adenocarcinoma is still unclear, increasing incidence of oesophageal cancer and mortality worldwide make its study necessary. Several investigations have been made on the aetiology of oesophageal cancer. Most of them assessed genetical or environmental factors. However, potential role of bacteria in the development of oesophageal adenocarcinoma as a new environmental factor has not been addressed. Previous study on Barrett's disease detected presence of Campylobacter concisus as a new emerging pathogen on Barrett's and oesophageal cancer samples compared with healthy individuals. This indicates that this organism might involve in the progression of Barrett's to oesophageal adenocarcinoma. Objectives: This study aimed to determine the effects of C. concisus on expression of three biomarkers including interleukin-18 (IL-18), tumour necrosis factor- $\alpha$ (TNF- $\alpha$ ) and tumour suppressor gene (p53) in three Barrett's cell lines.

Materials and Methods: Quantitative real-time PCR assays were developed to measure expression of pro-inflammatory mediators (IL-18 and TNF- $\alpha$ ) and gene expression of p53 in Barrett's cell lines in co-culture with C. concisus.

Results: The mentioned organism was able to modulate considerably expression of p53, TNF- $\alpha$ and IL-18 in a time-dependent manner.

Conclusions: The results showed that microorganism influences expression of carcinogenesis biomarker and cytokines in cell line models and possibility promotes oesophageal adenocarcinoma.
\end{abstract}

Keywords: Barrett Oesophagus, Interleukin-18, Tumour Necrosis Factor-alpha (TNF- $\alpha$ ), Genes, p53, Campylobacter concisus

\section{Background}

Barrett's oesophagus (BO) is a premalignant disorder at the end of oesophagus due to gastroesophageal reflux disease (GORD). It is known that $\mathrm{BO}$ is a progenitor of Oesophageal Adenocarcinoma (OA), which is a major cause of cancer death worldwide. Prevalence of BO is $0.2-2 \%$ annually in Western, Europe and the UK with 3-fold increase on the rate of OA over the last three decades. There have been various studies along with effective factors involved in the progression of $\mathrm{BO}$ to adenocarcinoma. Most of them have been focused on two major areas, genetical and/or environmental factors $(1,2)$. Recent evidences have revealed that alternation on oesophageal epithelium could result in colonising various pathogenic and non-pathogenic bacteria duo to new microenvironment. Study on BO biofilm showed that there are high level of atypical nitrate-reducing Campylobacters (especially Campylobacter concisus) in BO, compared with non-Barrett's samples $(3,4)$. Campylo- bacter concisus is a Gram-negative oral bacterium, which is supposed to be associated with inflammatory bowel disease, Crohn's disease and ulcerative colitis (5-8).

Campylobacter genus comprises 16 species and 6 subspecies, including important pathogens of humans and animals. The most significant species are C. jejuni, C. coli, C. fetus, and C. rectus, which cause a variety of infections such as gastroenteritis campylobacteriosis and periodontitis (9). Over the last decade, C. gracilis, C. upsaliensis and C. lari, especially C. concisus, have been linked to intestinal disease (8). Campylobacters express various virulence factors enabling them to adhere, invade and contribute to the evasion of host defence mechanisms. Different potent cytotoxic proteins and enzymes facilitate campylobacter virulence, such as haemolysin and cytolethal distending toxin (CDT) (10). Findings showed that C. concisus secretes 86 proteins, consists of 25 genes associated with

Copyright (C) 2015, Ahvaz Jundishapur University of Medical Sciences. This is an open-access article distributed under the terms of the Creative Commons Attribution-NonCommercial 4.0 International License (http://creativecommons.org/licenses/by-nc/4.0/) which permits copy and redistribute the material just in noncommercial usages, provided the original work is properly cited. 
virulence or colonisation activities $(6,10,11)$ and contains genotype and phenotype diversity (8). It can convert nitrate to nitrite, which leads to production of nitric oxide (carcinogenic agent). Clemons et al. (12) confirmed this characteristic of organism that how produced nitric oxide can affect the BO progression.

These all highlight ability of organism in adhesion and invasion of host cells. Evidence shows that microbe can invade intestinal epithelial cells, increase intestinal permeability, induce epithelial apoptosis in Caco2 cell line $(13,14)$ and interestingly induce inflammatory cytokines such as IL-6, IL-8, IL-10 in HT-29 (15), and IL-18 and TNF- $\alpha$ in BO cell lines (4). Considering these, data highlighted this hypothesis that $C$. concisus might play potential role in the aetiology of OA, an in vitro model of study was conducted to detect impact of organism on BO cell lines.

\section{Objectives}

This study aimed to investigate possible role of $C$. concisus in the expression of IL-18, TNF- $\alpha$ and p53 in BO cell lines as part of inflammatory key factors and intracellular signalling.

\section{Materials and Methods}

\subsection{Bacterial Strains}

Campylobacter concisus and Streptococcus salivarius strains used in this study had been isolated previously by Blackett et al. (4) from mucosal biopsies obtained from OA patients and healthy volunteers. Bacterial identities were verified by $16 \mathrm{~S}$ rRNA gene sequencing at Ninewells hospital, Dundee, UK and Blast search identified the most closely related strains to be C. concisus ATCC13826 and S. salivarius with accession number NC015760.1. Main organism was grown and sub-cultured on Wilkins-Chalgren agar (WC; Oxoid) supplemented with formate (0.6 $\left.\mathrm{gl}^{-1}\right)$, fumarate $\left(0.6 \mathrm{gl}^{-1}\right.$ ) (Sigma, Poole, Dorset, United Kingdom) in an anaerobic cabinet with $10 \% \mathrm{H}_{2}, 10 \% \mathrm{CO}_{2}$ and $80 \% \mathrm{~N}_{2}$ at $37^{\circ} \mathrm{C}$ (Don Whitley, United Kingdom). Before each test, organism was inoculated into WC broth in universal and incubated anaerobically at $37^{\circ} \mathrm{C}$. Bacteria were then centrifuged $(2500 \times \mathrm{g}, 25$ minutes $)$, washed once by PBS, counted in haemocytometer and resuspended to concentration of $3 \times 107 \mathrm{ml}^{-1}$. S. salivarius was grown aerobically in WC broth at $37^{\circ} \mathrm{C}$ for use as a negative control, as part of the normal human oesophageal microbiota (16).

\subsection{Cell Culture}

The Barrett's associated adenocarcinoma cell line FLO-1 (immortalised Barrett's oesophageal epithelial cells) and two Barrett's cell lines (CPA (non-dysplastic metaplasia) and CPD (high-grade dysplastic metaplasia)) were used to challenge with organism as described by Mozaffari Namin et al. (16). Briefly, FLO-1 was maintained in Dulbecco's modified eagle medium (DMEM) (Sigma-Aldrich,
Gillingham, UK) with 10\% foetal calf serum (FCS) (GibcoBRL life technologies, UK) and 1\% penicillin/ treptomycin (Gibco-BRL, UK). Barrett's cell lines in keratinocyte serumfree medium (KSFM) supplemented with $30 \mathrm{mgl}-1$ bovine pituitary extract (BPE), $0.2 \mu \mathrm{gl}-1$ recombinant epidermal growth factor (EPG) and $1 \%$ penicillin/streptomycin. Grown confluent cells were infected with pathogen and incubated at $37^{\circ} \mathrm{C}$ in $5 \% \mathrm{CO}_{2}-95 \% \mathrm{O}_{2}$ in humidified atmosphere for 1, 5 and 7 hours. At the end of each time point, supernatant was aspirated off, cells were harvested, centrifuged $(1000 \times \mathrm{g}$ for 5 minutes $)$ and cells pellets were kept at $-80^{\circ} \mathrm{C}$ for the rest of experiments. All cocultures were performed in triplicate and culture medium without bacteria was negative control.

\subsection{RNA Extraction, $c D N A$, $q P C R$}

Gene expression profile of biomarkers were determined by relative target gene quantities from threshold cycles $\left(C_{t}\right)$ normalised against the housekeeping gene GAPDH in FLO-1and BO cell lines through the mRNA extraction using the RNA easy kit (Qiagen, Crawley, UK), cDNA synthesis using the Quick reverse transcription system (Promega) and quantification by real-time PCR (qPCR) with primer sets after stimulating by $C$. concisus as described previously by Mozaffari Namin et al. (16). Briefly, products of correct size and sequence were purified using the Qiaquick PCR purification kit and ligated into a vector using the pGEM-T easy vector system I (Promega). Plasmid DNA from candidate clones was isolated and purified using the Wizard plus SV miniprep system (Promega) and the sequence identity verified. Samples were diluted to $10^{10}$ molecules $\mu \mathrm{l}^{-1}$, aliquoted and stored at $-80^{\circ} \mathrm{C}$. qPCR was performed using an iCycler real-time PCR detection system (BioRad laboratories, Hercules, CA, USA) in the presence of iQ SYBR Green Supermix (BioRad). The standard amplification protocol consisted of an initial denaturation step $\left(95^{\circ} \mathrm{C}, 3\right.$ minutes $)$, followed by 38 cycles of $95^{\circ} \mathrm{C}$ for 30 seconds, 30 seconds at appropriate annealing temperature (Table 1) and one final denaturation cycle $\left(95^{\circ} \mathrm{C}, 30\right.$ seconds).

\subsection{Statistical Analysis}

GraphPad Prism, version 4 (GraphPad software Inc. San Diego, CA) was used for data analysis. Repeated-measurement two-way ANOVA analysis with Bonferroni post-hoc test was used for comparison of different groups. PValues $<0.05$ were considered as statistically significant.

\section{Results}

\subsection{Effects of Campylobacter concisus on Cellular Biomarker Expression}

Molecular analyses showed that $C$. concisus has had remarkable effects on the expression of three cellular biomarkers. Significant differences were observed on the expression of p53 ( $\mathrm{P}<0.001)$, TNF- $\alpha(\mathrm{P}<0.05)$ and IL-18 (P $<0.001)$ in FLO-1 cell line compared to the control (Table 
2). The highest difference on the expression of p53 was detected on CP-A cells after one hour $(\mathrm{P}<0.01)$. TNF- $\alpha$ and IL-18 had not been expressed considerably in this cell line, although there was a slight increase during time points (Table 3). Significant folds gene expression of IL-18 was defined on CP-D cells where there was a gradual increase between 1 and 7 hours $(\mathrm{P}<0.001)$. However, the impact of bacterium was not as much as control on the expression of TNF- $\alpha$ and p53 (Table 4).
4.2. Effects of Streptococcus salivarius on Cellular Biomarkers

Streptococcus salivarius was selected as a commensal bacterium to test its effects on the expression of selected biomarkers in contrast to C. concisus. Results showed no significant effects on the expression of biomarkers except a slight increase on p53 expression, which might be test error (Table 5).

\begin{tabular}{|c|c|c|c|c|c|}
\hline Primer Set & Primer Sequence (5' - 3') & Target Group & $\mathbf{T m},{ }^{\circ} \mathrm{C}$ & Product Size, bp & Reference \\
\hline Camp & & Campylobacter concisus & 60 & 306 & (17) \\
\hline $\mathrm{F}$ & CAGTATCGGCAATTCGCT & & & & \\
\hline $\mathrm{R}$ & GACAGTATCAAGGATTTACG & & & & \\
\hline IL-18 & & interleukin 18 & 65 & 105 & this study \\
\hline $\mathrm{F}$ & GACGCATGCCCTCAATCC & & & & \\
\hline $\mathrm{R}$ & CTAGAGCGCAATGGTGCAATC & & & & \\
\hline TNF- $\alpha$ & & tumour necrosis factor- $\alpha$ & 56 & 123 & (18) \\
\hline $\mathrm{F}$ & TCTCGAACCCCGAGTGACAA & & & & \\
\hline $\mathrm{R}$ & TATCTCTCAGCTCCACGCCA & & & & \\
\hline GAPDH & & $\begin{array}{l}\text { glyceraldehyde-3-phosphate } \\
\text { dehydrogenase }\end{array}$ & 56 & 183 & (18) \\
\hline $\mathrm{F}$ & GGAAGGTGAAGGTCGGAGTC & & & & \\
\hline $\mathrm{R}$ & TCAGCCTTGACGGTGCCATG & & & & \\
\hline p53 & & tumour suppressor gene & 61 & 120 & (19) \\
\hline F & CAGCCAAGTCTGTGACTTGCA & & & & \\
\hline $\mathrm{R}$ & GTGTGGAATCAACCCACAGCT & & & & \\
\hline
\end{tabular}

${ }^{a}$ Abbreviations: $\mathrm{Tm}$, annealing temperature; bp, base pairs.

\begin{tabular}{|c|c|c|c|c|c|}
\hline \multirow[t]{2}{*}{ Biomarkers } & \multicolumn{4}{|c|}{ Time, $\mathbf{h}$} & \multirow[t]{2}{*}{ PValue } \\
\hline & $\mathbf{1}$ & 3 & 5 & 7 & \\
\hline p53 & & & & & $<0.001$ \\
\hline $\mathrm{T}$ & $677 \pm 3$ & $417 \pm 3.26$ & $238 \pm 2.2$ & $201 \pm 2$ & \\
\hline $\mathrm{C}$ & $198 \pm 2$ & $166 \pm 2.21$ & $205 \pm 1.2$ & $182 \pm 1$ & \\
\hline IL-18 & & & & & $<0.05$ \\
\hline $\mathrm{T}$ & $804 \pm 1.5$ & $2053 \pm 1.39$ & $3566 \pm 1.82$ & $2009 \pm 0.95$ & \\
\hline $\mathrm{C}$ & $2924 \pm 1.65$ & $2649 \pm 2.65$ & $2840 \pm 1.45$ & $2521 \pm 1.72$ & \\
\hline TNF $\alpha$ & & & & & $<0.001$ \\
\hline $\mathrm{T}$ & $30 \pm 3$ & $277 \pm 2.16$ & $433 \pm 3.45$ & $251 \pm 3.23$ & \\
\hline $\mathrm{C}$ & $53 \pm 3$ & $64 \pm 2.45$ & $81 \pm 3.2$ & $65 \pm 3.5$ & \\
\hline
\end{tabular}


Mozaffari Namin B et al.

\begin{tabular}{|c|c|c|c|c|c|}
\hline \multirow[t]{2}{*}{ Biomarkers } & \multicolumn{4}{|c|}{ Time, h } & \multirow[t]{2}{*}{ P Value } \\
\hline & $\mathbf{1}$ & 3 & 5 & 7 & \\
\hline p53 & & & & & $<0.01$ \\
\hline $\mathrm{T}$ & $20568 \pm 3.35$ & $1684 \pm 3.1$ & $952 \pm 2.92$ & $672 \pm 2.68$ & \\
\hline C & $2331 \pm 2.3$ & $2830 \pm 3.1$ & $2241 \pm 3$ & $2665 \pm 3.3$ & \\
\hline IL-18 & & & & & $<0.001$ \\
\hline $\mathrm{T}$ & $387 \pm 1.1$ & $401 \pm 1.5$ & $1395 \pm 2.8$ & $805 \pm 1.95$ & \\
\hline $\mathrm{C}$ & $1536 \pm 1.65$ & $1758 \pm 1.5$ & $1589 \pm 1.72$ & $1637 \pm 1.52$ & \\
\hline TNF- $\alpha$ & & & & & $<0.001$ \\
\hline $\mathrm{T}$ & $74 \pm 1.52$ & $27 \pm 1$ & $51 \pm 1.3$ & $568 \pm 3.23$ & \\
\hline C & $3127 \pm 2.8$ & $3557 \pm 3$ & $3597 \pm 3.2$ & $3805 \pm 3.5$ & \\
\hline
\end{tabular}

abbreviations: $\mathrm{T}$, test; $\mathrm{C}$, control.

${ }^{b}$ Results are means \pm SEM from three independent experiments compared with non-stimulated controls, analysed by two-way ANOVA followed by Bonferroni post-test analysis.

\begin{tabular}{|c|c|c|c|c|c|}
\hline \multirow[t]{2}{*}{ Biomarkers } & \multicolumn{4}{|c|}{ Time, h } & \multirow[t]{2}{*}{ P Value } \\
\hline & 1 & 3 & 5 & 7 & \\
\hline p53 & & & & & $<0.05$ \\
\hline $\mathrm{T}$ & $7494 \pm 1.2$ & $7789 \pm 1.62$ & $10343 \pm 2.32$ & $15836 \pm 2.68$ & \\
\hline $\mathrm{C}$ & $15668 \pm 5.1$ & $14846 \pm 4.7$ & $13905 \pm 6$ & $15053 \pm 5.3$ & \\
\hline IL-18 & & & & & $<0.001$ \\
\hline $\mathrm{T}$ & $1196 \pm 1.65$ & $1335 \pm 1.75$ & $1208 \pm 3.6$ & $1285 \pm 2.95$ & \\
\hline C & $645 \pm 1.6$ & $651 \pm 2$ & $726 \pm 2.72$ & $745 \pm 3.52$ & \\
\hline TNF $\alpha$ & & & & & $<0.001$ \\
\hline $\mathrm{T}$ & $8.5 \pm 1.3$ & $5.8 \pm 1$ & $180 \pm 3.3$ & $656 \pm 4.5$ & \\
\hline C & $5847 \pm 3$ & $7061 \pm 3.8$ & $7423 \pm 5.2$ & $6718 \pm 4.5$ & \\
\hline
\end{tabular}

abbreviations: $\mathrm{T}$, test; $\mathrm{C}$, control.

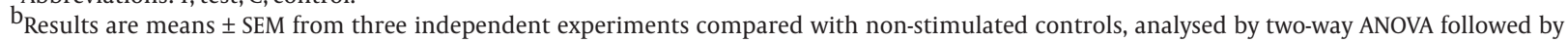
Bonferroni post-test analysis.

\begin{tabular}{|c|c|c|c|c|c|}
\hline \multirow[t]{2}{*}{ Biomarkers } & \multicolumn{4}{|c|}{ Time, h } & \multirow[t]{2}{*}{ PValue } \\
\hline & 1 & 3 & 5 & 7 & \\
\hline p53 & & & & & 0.86 \\
\hline $\mathrm{T}$ & $3206 \pm 1.7$ & $3311 \pm 1.62$ & $2147 \pm 1.32$ & $2550 \pm 1.68$ & \\
\hline $\mathrm{C}$ & $2898 \pm 6.9$ & $2837 \pm 4.7$ & $2822 \pm 6$ & $2991 \pm 5.3$ & \\
\hline IL-18 & & & & & 0.12 \\
\hline $\mathrm{T}$ & $4.5 \pm 1.45$ & $4.75 \pm 1.35$ & $4.25 \pm 1.2$ & $4.5 \pm 1.29$ & \\
\hline $\mathrm{C}$ & $7 \pm 2$ & $7.5 \pm 2.2$ & $7 \pm 1.72$ & $7.5 \pm 2.52$ & \\
\hline TNF- $\alpha$ & & & & & $<0.001$ \\
\hline $\mathrm{T}$ & $275 \pm 1.45$ & $415 \pm 1.78$ & $490 \pm 1.35$ & $650 \pm 1.45$ & \\
\hline $\mathrm{C}$ & $4534 \pm 2.3$ & $5580 \pm 2.8$ & $6120 \pm 2.2$ & $4370 \pm 2.5$ & \\
\hline
\end{tabular}

\footnotetext{
a Abbreviations: T, test; C, control.

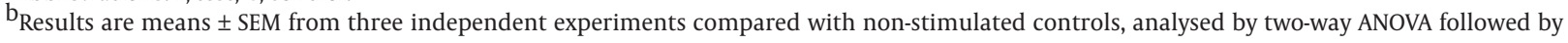
Bonferroni post-test analysis. 


\section{Discussion}

Barrett's oesophagus is recognised as a metaplastic columnar-lined epithelium, which is caused by GORD and predisposes to OA (12). There are various inflammatory responses and gene expression through the progression of BO to OA (20). However, using cell culture model of Barrett's cell lines demonstrated that organism could increase significantly expression of p53, IL-8, and TNF- $\alpha$ in FLO- 1 cells. Results showed that considerable influence of C. concisus was detected on the expression of p53 in CP-A (non-dysplastic cells) and IL-18 in CP-D (dysplastic cells).

Cellular and molecular alternation has been investigated on the expression of inflammatory cytokines such as IL-1 $\beta$, TNF- $\alpha$, IFN $\Upsilon$, IL-18 and p53 gene. Investigations on IL-18, which is mainly produced by dendritic cells and macrophages, revealed that it influences upregulation of IL-1 $\beta$, TNF- $\alpha$ and IFNY (21). In 2007, Ye et al. (22) presented that high level of IL-18 expression in gastric cancer compared with control group facilitates cancer cell metastasis, and also induces NF-kB pathway to regulate cell proliferation and transformation. The role of IL18 in induction of different cytokines (IL-1, IL-10, TNF- $\alpha$ ) has been documented in gastric and colon cancers and during tumour cell proliferation (23). Detection of proinflammatory cytokines (TNF- $\alpha$, IL-18) in the early stages of BO would be useful to identify the progression of OA, since an association between chronic inflammation and BO has been reported (24). Man et al. (9) reported that $C$. concisus could adhere and invade intestinal Caco2 and HT29 cell lines and release inflammatory cytokines (IL$1 \beta$, IL-8 and TNF- $\alpha$ ). Similarly, this study showed that bacterium is able to express considerable IL-18 in CP-D and FLO-1 cell lines.

Second selected biomarker was the expression of TNF- $\alpha$. It acts as a tumour promoter, induces assembling complex receptors, such as TNF-receptor-1 and the Jun kinase (JNK) cascade to control cell survival and death by interplaying between NF- $\mathrm{B}$ and JNK (25). TNF- $\alpha$ is usually activated through multiple intracellular signalling pathways involving NF-k $\beta$, MAPK (mitogen activated protein kinase) and p38 $(26,27)$. It is expressed at low level in normal squamous epithelium, while its expression increases through the progression of $\mathrm{BO}$ signifying a role in the $\mathrm{OA}$ evolution (28). This indicates the association between TNF- $\alpha$, interleukins and NF-k $\beta$. It is known that NF-k $\beta$ contributes in upregulation of genes involved in pro-inflammatory cytokine formation, apoptosis blocking and cell proliferation and differentiation.

There is also no activated NF-k $\beta$ in normal oesophageal cells; however, it has been detected in BO and OA $(21,29,30)$. Activation of NF-k $\beta$ via induction of TNF- $\alpha$ and IL-18 through chronic infection enhances the possibility of activation of carcinogenesis sequences. Similarly, stimulation of NF-k $\beta$ pathway in Crohn's disease by the effect of NOD2 gene (31), in gastric cancer NOD1 gene by the effect of $H$. pylori (32) and in lung cancer NOD1 by the influence of Chlamydophi- la pneumoniea (33) increases putative role of C. concisus in the pathogenesis of BO transformation. Our findings confirmed that microbe could induce increasingly expression of TNF- $\alpha$ on FLO-1 cell line, while its expression on non-dysplastic (CP-A) and dysplastic (CP-D) cell lines were not higher than control in spite of increasing during the time of culture. The impact of $C$. concisus has also been confirmed in Chinese hamster ovary cells regarding cytolytic effect of organism (34) and its influence on the induction of IL-12 and NF-k $\beta(6)$.

Another detectable biomarker in Barrett's transformation is p53. Any alternations in the p53 gene would result in various abnormalities and genetical damage. Alternations of p53 gene in BO increase 16-fold risk of OA than those without any abnormalities on p53 (35). However, molecular epidemiology has indicated that the prevalence of positive p53 immunoreactivity in different stages of Barrett's (metaplasia-low dysplasiahigh dysplasia-adenocarcinoma) linked to the significant rates of p53 overexpression. These specify that p53 can be induced in early stages of BO via environmental factors, which lead to abnormalities in the cell cycle (36). Subsequently, recognition of induced p53 in different stages of $\mathrm{BO}$ movement accounts for the progression of oesophageal cancer. Providing that $C$. concisus induces the operation of signalling pathways to activate p53, it would create genetic instability to establish cellular abnormalities. Evidence indicated an increasing expression of p53 and cell proliferation in correlation with progression of BO between GORD, $\mathrm{BO}$ and $\mathrm{OA}$ patients, and suppression of p53 in dysplastic stage $(27,37-39)$. This study showed that $C$. concisus could express significantly p53 in FLO-1 cells, after one hour in CP-A and after seven hours in CP-D; whereas, the major effect was observed in FLO-1 cell line.

This investigation showed that although each of the molecular markers is expressed at different stages of BO transformation, there are close association between their activation and induction of multiple cellular pathways. This study highlighted notable results on the expression of biomarkers compared with the effect of commensal bacterium (S. salivarius), which had no considerable impact on the expression of selected biomarkers and can be used in understanding pathogenesis of OA. However, it is early to complete this and there might be a set of unrecognised factors in activating or supressing different biomarkers in BO progression. This study suggested possible pathogenic role of $C$. concisus in initiation or induction of $\mathrm{BO}$ to $\mathrm{OA}$ as a novel idea to be investigated in further researches.

In conclusion, beside various studies about cellular and molecular mechanisms of BO transformation, we postulated that $\mathrm{BO}$ creates a new microenvironment in which BO biofilm specifically $C$. concisus might facilitate induction or exacerbation of BO progression through chronic inflammation. 


\section{Acknowledgments}

Author would like to thank the head of microbiology and gut group of Dundee university and grateful to all lab staff of Dundee university and school of public health, Tehran university of medical sciences who participated in and supported this work.

\section{Footnotes}

Authors' Contribution:Analysis, interpretation, drafting of the manuscript, statistical analysis and revision: Behrooz Mozaffari Namin; Providing feedback on manuscript: Mohammad Mehdi Soltan Dallal, Nasser Ebrahimi Daryani.

Funding/Support:This work was semi-funded by international campus (TUMS-IC), the vice-chancellor for Research grant (NO. 24099) of Tehran university of medical sciences (Tehran, Iran).

\section{References}

1. Spechler SJ, Fitzgerald RC, Prasad GA, Wang KK. History, molecular mechanisms, and endoscopic treatment of Barrett's esophagus. Gastroenterology. 2010;138(3):854-69. doi: 10.1053/j. gastro.2010.01.002. [PubMed: 20080098]

2. de Jonge PJ, van Blankenstein M, Grady WM, Kuipers EJ. Barrett's oesophagus: epidemiology, cancer risk and implications for management. Gut. 2014;63(1):191-202. doi: 10.1136 gutjnl-2013-305490. [PubMed: 24092861]

3. Yang L, Lu X, Nossa CW, Francois F, Peek RM, Pei Z. Inflammation and intestinal metaplasia of the distal esophagus are associated with alterations in the microbiome. Gastroenterology. 2009;137(2):588-97. doi: 10.1053/j.gastro.2009.04.046. [PubMed: 19394334]

4. Blackett KL, Siddhi SS, Cleary S, Steed H, Miller MH, Macfarlane S, et al. Oesophageal bacterial biofilm changes in gastro-oesophageal reflux disease, Barrett's and oesophageal carcinoma: association or causality? Aliment Pharmacol Ther. 2013;37(11):1084-92. doi:10.1111/apt.12317. [PubMed: 23600758]

5. Macfarlane GT, Blackett KL, Nakayama T, Steed H, Macfarlane S. The gut microbiota in inflammatory bowel disease. Curr Pharm Des. 2009;15(13):1528-36. [PubMed: 19442170]

6. Kaakoush NO, Deshpande NP, Wilkins MR, Tan CG, Burgos Portugal JA, Raftery MJ, et al. The pathogenic potential of Campylobacter concisus strains associated with chronic intestinal diseases. PLoS One. 2011;6(12):e29045. doi: 10.1371/journal. pone.0029045. [PubMed: 22039478]

7. Mukhopadhya I, Thomson JM, Hansen R, Berry SH, El-Omar EM, Hold GL. Detection of Campylobacter concisus and other Campylobacter species in colonic biopsies from adults with ulcerative colitis. PLoS One. 2011;6(6):e21490. doi: 10.1371/journal. pone.0021490. [PubMed: 22039478]

8. Kaakoush NO, Mitchell HM. Campylobacter concisus - A new player in intestinal disease. Front Cell Infect Microbiol. 2012;2:4. doi:10.3389/fcimb.2012.00004. [PubMed: 22919596]

9. Man SM, Kaakoush NO, Leach ST, Nahidi L, Lu HK, Norman J, et al. Host attachment, invasion, and stimulation of proinflammatory cytokines by Campylobacter concisus and other non-Campylobacter jejuni Campylobacter species. J Infect Dis. 2010;202(12):1855-65. doi: 10.1086/657316. [PubMed: 21050118]

10. Kaakoush NO, Man SM, Lamb S, Raftery MJ, Wilkins MR, Kovach $\mathrm{Z}$, et al. The secretome of Campylobacter concisus. FEBS J. 2010;277(7):1606-17. doi: 10.1111/j.1742-4658.2010.07587.x. [PubMed: 20148967]

11. Mahendran V, Tan YS, Riordan SM, Grimm MC, Day AS, Lemberg $\mathrm{DA}$, et al. The prevalence and polymorphisms of zonula occluden toxin gene in multiple Campylobacter concisus strains isolated from saliva of patients with inflammatory bowel disease and controls. PLoS One. 2013;8(9):e75525. doi: 10.1371/journal. pone.0075525. [PubMed: 24086553]

12. Clemons NJ, Phillips WA, Lord RV. Signaling pathways in the molecular pathogenesis of adenocarcinomas of the esophagus and gastroesophageal junction. Cancer Biol Ther. 2013;14(9):782-95. doi:10.4161/cbt.25362. [PubMed:23792587]

13. Man SM, Zhang L, Day AS, Leach ST, Lemberg DA, Mitchell H. Cam pylobacter concisus and other Campylobacter species in children with newly diagnosed Crohn's disease. Inflamm Bowel Dis 2010;16(6):1008-16. doi:10.1002/ibd.21157. [PubMed:19885905]

14. Ismail Y, Mahendran V, Octavia S, Day AS, Riordan SM, Grimm MC et al. Investigation of the enteric pathogenic potential of oral Campylobacter concisus strains isolated from patients with inflammatory bowel disease. PLoS One. 2012;7(5):e38217. doi:10.1371| journal.pone.0038217. [PubMed:22666490]

15. Kalischuk LD, Inglis GD. Comparative genotypic and pathogenic examination of Campylobacter concisus isolates from diarrheic and non-diarrheic humans. BMC Microbiol. 2011;11:53. doi: 10.1186/1471-2180-11-53. [PubMed: 21406111]

16. Mozaffari Namin B, Daryani NE, Mirshafiey A, Yazdi MK, Dallal MM. Effect of probiotics on the expression of Barrett's oesophagus biomarkers. J Med Microbiol. 2015;64(Pt 4):348-54. doi: 10.1099/jmm.0.000039. [PubMed: 25666837]

17. Engberg J, Bang DD, Aabenhus R, Aarestrup FM, Fussing V, GernerSmidt P. Campylobacter concisus: an evaluation of certain phenotypic and genotypic characteristics. Clin Microbiol Infect. 2005;11(4):28895. doi:10.1111/j.1469-0691.2005.01111.x. [PubMed:15760425]

18. Furrie E, Macfarlane S, Kennedy A, Cummings JH, Walsh SV, O'Neil D A, et al. Synbiotic therapy (Bifidobacterium longum/ Synergy 1) initiates resolution of inflammation in patients with active ulcerative colitis: a randomised controlled pilot trial Gut. 2005;54(2):242-9. doi: 10.1136/gut.2004.044834. [PubMed: 15647189]

19. Bourdon JC, Fernandes K, Murray-Zmijewski F, Liu G, Diot A, Xirodimas DP, et al. p53 isoforms can regulate p53 transcriptional activity. Genes Dev. 2005;19(18):2122-37. doi:10.1101/gad.1339905. [PubMed: 16131611]

20. Younes M. Molecular Pathology of Barrett's Metaplasia and Esophageal Adenocarcinoma. In: Sepulveda AR, Lynch JP, editors. Molecular Pathology of Neoplastic Gastrointestinal Diseases. US: Springer; 2013. pp. 43-52.

21. Abdel-Latif MM, O'Riordan J, Windle HJ, Carton E, Ravi N, Kelleher $\mathrm{D}$, et al. NF-kappaB activation in esophageal adenocarcinoma: relationship to Barrett's metaplasia, survival, and response to neoadjuvant chemoradiotherapy. Ann Surg. 2004;239(4):491-500. [PubMed: 15024310]

22. Ye ZB, Ma T, Li H, Jin XL, Xu HM. Expression and significance of intratumoral interleukin-12 and interleukin-18 in human gastric carcinoma. World J Gastroenterol. 2007;13(11):1747-51. [PubMed: 17461482]

23. Thong-Ngam D, Tangkijvanich P, Lerknimitr R, Mahachai V, Theamboonlers A, Poovorawan Y. Diagnostic role of serum interleukin-18 in gastric cancer patients. World $J$ Gastroenterol. 2006;12(28):4473-7. [PubMed: 16874857]

24. Colleypriest BJ, Ward SG, Tosh D. How does inflammation cause Barrett's metaplasia? Curr Opin Pharmacol. 2009;9(6):721-6. doi: 10.1016/j.coph.2009.09.005. [PubMed: 19828375]

25. Karin M. Nuclear factor-kappaB in cancer development and progression. Nature. 2006;441(7092):431-6. doi: 10.1038/nature04870. [PubMed:16724054]

26. Rahman MM, McFadden G. Modulation of NF-kappaB signalling by microbial pathogens. Nat Rev Microbiol. 2011;9(4):291-306. doi: 10.1038/nrmicro2539. [PubMed: 21383764]

27. Abdel-Latif MM, Kelleher D, Reynolds JV. Potential role of NF-kappaB in esophageal adenocarcinoma: as an emerging molecular target. J Surg Res. 2009;153(1):172-80. doi: 10.1016/j.jss.2007.12.755. [PubMed: 18533190]

28. Tselepis C, Perry I, Dawson C, Hardy R, Darnton SJ, McConkey C, et al. Tumour necrosis factor-alpha in Barrett's oesophagus: a potential novel mechanism of action. Oncogene. 2002;21(39):607181. doi:10.1038/sj.onc.1205731. [PubMed:12203119] 
29. Gibson MK, Dhaliwal AS, Clemons NJ, Phillips WA, Dvorak K, Tong D, et al. Barrett's esophagus: cancer and molecular biology. Ann N Y Acad Sci. 2013;1300:296-314. doi: 10.1111/nyas.12252. [PubMed: 24117650]

30. Picardo SL, Maher SG, O'Sullivan JN, Reynolds JV. Barrett's to oesophageal cancer sequence: a model of inflammatory-driven upper gastrointestinal cancer. Dig Surg. 2012;29(3):251-60. doi: 10.1159/000341498. [PubMed: 22868386]

31. Kaparakis M, Turnbull L, Carneiro L, Firth S, Coleman HA, Parkington $\mathrm{HC}$, et al. Bacterial membrane vesicles deliver peptidoglycan to NOD1 in epithelial cells. Cell Microbiol. 2010;12(3):372-85. doi:10.1111/j.1462-5822.2009.01404.x. [PubMed:19888989]

32. Viala J, Chaput C, Boneca IG, Cardona A, Girardin SE, Moran AP, et al. Nod1 responds to peptidoglycan delivered by the Helicobacter pylori cag pathogenicity island. Nat Immunol. 2004;5(11):1166-74. doi:10.1038/ni1131. [PubMed:15489856]

33. Opitz B, Forster S, Hocke AC, Maass M, Schmeck B, Hippenstiel S, et al. Nod1-mediated endothelial cell activation by Chlamydophila pneumoniae. Circ Res. 2005;96(3):319-26. doi: 10.1161/01. RES.0000155721.83594.2c. [PubMed: 15653568]

34. Istivan TS, Smith SC, Fry BN, Coloe PJ. Characterization of Campylobacter concisus hemolysins. FEMS Immunol Med Microbiol. 2008;54(2):224-35. doi: 10.1111/j.1574-695X.2008.00467.x.
[PubMed:18754784]

35. Gajjar M, Candeias MM, Malbert-Colas L, Mazars A, Fujita J, Olivares-Illana V, et al. The p53 mRNA-Mdm2 interaction controls Mdm2 nuclear trafficking and is required for p53 activation following DNA damage. Cancer Cell. 2012;21(1):25-35. doi: 10.1016/j. ccr.2011.11.016. [PubMed:22264786]

36. Fichter CD, Herz C, Munch C, Opitz OG, Werner M, Lassmann S. Occurrence of multipolar mitoses and association with AuroraA/-B kinases and p53 mutations in aneuploid esophageal carcinoma cells. BMC Cell Biol. 2011;12:13. doi: 10.1186/1471-2121-12-13. [PubMed: 21470402]

37. Hritz I, Gyorffy H, Molnar B, Lakatos G, Sipos F, Pregun I, et al. Increased p53 expression in the malignant transformation of Barrett's esophagus is accompanied by an upward shift of the proliferative compartment. Pathol Oncol Res. 2009;15(2):183-92. doi:10.1007/s12253-008-9095-z. [PubMed: 18752044]

38. Zarrilli R, Ricci V, Romano M. Molecular response of gastric epithelial cells to Helicobacter pylori-induced cell damage. Cell Microbiol.1999;1(2):93-9. [PubMed:11207544]

39. Hofman VJ, Moreilhon C, Brest PD, Lassalle S, Le Brigand K, Sicard $D$, et al. Gene expression profiling in human gastric mucosa infected with Helicobacter pylori. Mod Pathol. 2007;20(9):974-89. doi:10.1038/modpathol.3800930. [PubMed: 17643099] 